\title{
Banking supervision and the special resolution regime of the Banking Act 2009: the unfinished reform
} Emilios Avgouleas*

\section{Key points}

- One of the fundamental rationales underpinning banking regulation and justifying the costs it entails is the prevention of banking failures and associated depositor runs. This is exactly what the UK regulators could not prevent during the Northern Rock crisis. Apart from the much discussed regulatory failures, the Northern Rock crisis also exposed the absence of an effective legal system dealing with failing banks.

- The Banking Act 2009 introduces a number of important and far reaching reforms, including a Special Resolution Regime (SRR) for failing banks. The reforms address several of the identified regulatory loopholes. Thus, the Act constitutes a significant improvement over the previous regime.

- Yet the Act does not seek to reform banking supervision arrangements, even though these have become the subject of considerable criticism. This article argues that, in addition to other reasons, the effective operation of the SRR requires the reform of the institutional structures of the UK system of banking supervision. Otherwise the serious governance challenges and distributional issues the SRR creates may seriously undermine the standing of the SRR authorities, namely, the Treasury, the FSA, and the Bank of England, and have an adverse impact on the effectiveness of the new regime.

\section{Introduction}

The global financial crisis repeatedly brought the international banking system to the brink of collapse in the course of 2008 and it still continues in full force. What started, in its first phase in August 2007, as a severe credit crunch became, in its second phase, following the collapse of Lehman Brothers in early September 2008, a full blown global financial crisis. The first institution to fall victim of the credit crunch was the British mortgage provider Northern Rock, in September 2007. The very public failure of this institution triggered a depositors' run providing strong and clear signals that the UK system of banking supervision presented serious cracks.

The main objectives of banking regulation are the protection of investors, and the prevention of bank failures and depositor runs as well as the minimization of the risk of contagion that these may create. ${ }^{1}$ There are four acceptable ways to deal with a failing bank: (a) liquidity support, (b) full insurance cover of deposits, (c) public rescue or private transfer, (d) a special bankruptcy regime. Depending on the circumstances all of the above might have to be used concurrently. The applicable regulatory framework seemed to prevent the Tripartite Authorities (HM Treasury, BoE and the FSA) from

\footnotetext{
* Reader in International Financial Law, School of Law, University of Manchester.

1 R Cranston, Principles of Banking Law (2nd edn OUP, Oxford 2002), ch. 3, and R Dale, The Regulation of International Banking (Prentice Hall, London 1984), ch 3. Other commentators add a third objective the minimization of the public cost of bank failures. See also C Goodhart et al., Financial Regulation: Why, How and Where Now? (Routledge, London 1998), ch 1.
} 
using any of those techniques in an effective manner during the Northern Rock crisis. According to its many critics the Tripartite agreement between the FSA, the Treasury and the Bank, which was concluded following the transfer of banking supervision to the FSA from the BoE, simply did not work.

The Northern Rock failure was followed by political recriminations, severe criticism of the FSA's style of supervision and the Bank's handling of the crisis. The Parliamentary enquiry into the Northern Rock crisis, ${ }^{2}$ which considered in detail the conduct of the FSA and of the Bank of England (BoE), offered severe criticism of the actions of both institutions, but clearly reserved its harshest criticism for the FSA. Parliament's enquiry highlighted serious loopholes in the UK's banking supervision, regulation of systemic stability arrangements, and the administration of liquidity support facilities. However, the Parliament Committee hearings stressed above all the debilitating impact of the absence of a special resolution regime (SRR) dealing with failing banks. ${ }^{3}$

In the aftermath of the crisis the Treasury was vested with additional powers relating to the compulsory acquisition of shares in failing banks and transfer of their property when they pose a serious threat to the UK's financial system and in order to protect the public interest. ${ }^{4}$ In addition the Tripartite Authorities issued in late 2007 and in the course of 2008 a number of consultation papers discussing suggested changes in the UK depositor protection and financial stability regimes ${ }^{5}$ and the establishment of a permanent SRR for failing banks. ${ }^{6}$

In September and October 2008 several very large UK banks faced the near certain prospect of collapse. During the same period the banking systems of most EU member states and of the USA were under a similar threat. In order to avert a total meltdown of their banking systems, the UK, other EU member states and the USA adopted very costly public rescue packages of their ailing banks putting significant emphasis on re-capitalization. Following the adoption of its rescue package for UK banks, ${ }^{7}$ the Treasury introduced a new Banking Act. ${ }^{8}$

2 House of Commons, Treasury Committee, Fifth Report of Session 2007-08, 'The Run on the Rock', 24 January 2008. [Hereinafter The Run on the Rock].

3 Ibid 81-83.

4 Banking (Special Provisions) Act 2008, ch 2. The Act expired in February 2009.

5 Tripartite Authorities (HM Treasury, FSA, BoE), 'Financial Stability and Depositor Protection: Further Consultation' (Cm 7436, 2008); FSA, 'Review of the Liquidity Requirements for Banks and Building Societies', December 2007; Tripartite Authorities (HM Treasury, FSA, BoE), 'Banking Reform - Protecting Depositors: A Discussion Paper', October 2007.

6 HM Treasury, 'Financial Stability and Depositor Protection: Special Resolution Regime' (Cm 7459, 2008).

7 The UK Treasury's package aimed to ensure the stability of the financial system and to protect ordinary savers, depositors, businesses and borrowers. Apart from providing sufficient liquidity in the short term through the Bank of England's Special Liquidity Scheme, the Government provided a guarantee of short and medium bank debt in order to ensure that the banking system had the funds necessary to maintain lending in the medium term. It also forced banks drawing from the rescue scheme to re-capitalize reinforcing their capital base. The Treasury undertook to underwrite the share capital increases of participating institutions and take equity stakes in the banks concerned by means of preference shares. See 'The Treasury's Statement on a Bailout for British Banks to Rescue the Financial Sector from the Turmoil of Recent Days', The Telegraph, 8 October 2008, available at $<\mathrm{http} / /$ www.telegraph.co.uk/finance/financetopics/financialcrisis/3156569/Banking-bailout-The-statement-in-full.html > last accessed on 10 November 2008.

8 Banking Act 2009, c 1. 
The Act incorporates the conclusions of the consultations that took place in the previous months and is the product of accumulated experience gathered not only from the Northern Rock crisis, but also from the more recent global financial crisis that also necessitated the nationalization, in a much more orderly manner than Northern Rock, of the mortgage lender Bradford and Bingley. ${ }^{9}$ Essentially, it constitutes the most important reform of UK banking regulation, especially with respect to the framework for banking supervision and financial stability, since the introduction of FSMA 2000. The reforms introduced by the Banking Act intend to serve five core high-level objectives: ${ }^{10}$

- strengthening the stability and resilience of the UK financial system,

- reducing the likelihood of individual banks facing difficulties,

- reducing the impact if, nevertheless, banks do get into difficulties,

- ensuring effective protection for depositors, in the event of a bank failure, and

- strengthening the Bank of England, and ensuring effective coordinated actions by authorities, both in the UK and internationally.

The first reform introduced by the Act is the establishment of a permanent SRR dealing with failing banks. The SRR consists of: (a) the three stabilization options, (b) a special bank insolvency procedure and (c) a special bank administration procedure. The SRR described in the Act is a hybrid regime and bears limited resemblance to the one in the United States, where the Federal Deposit Insurance Corporation (FDIC) has the ability to take a failing bank into federal administration.

The three stabilization options refer to: (a) transfer to a private sector purchaser ${ }^{11}$ through a transfer of shares or property, (b) transfer of property from a failing bank to a bridge bank ${ }^{12}$ (a new company owned by the BoE) and (c) temporary public ownership (TPO). ${ }^{13}$ The TPO option is exercised through the transfer of shares to the public sector and is administered by the Treasury. What is striking here and indicative of the allsweeping powers accorded to the Treasury under the Act is that the Treasury may, under Section 82, exercise the same SRR option to bring under TPO the parent undertaking of a bank ('holding company'), if it is formed under any part of UK law.

Each of the three stabilization options is achieved through the exercise of one or more of the stabilization powers, which are: (a) share transfer powers and (b) property transfer powers. Accordingly, the stabilization powers consist of either a total or partial transfer of ownership in the distressed bank or a total or partial transfer of its property, assets, rights and liabilities.

As explained in section 3 of this article, where an analytical overview of the SRR is offered, the BoE takes the lead role in the implementation of the SRR, taking the decisions on which SRR tools (other than temporary public ownership) to use with respect to a failing bank and the FSA decides whether a bank should enter the SRR.

\footnotetext{
9 David Gow, 'European Commission Backs Bradford \& Bingley Rescue Plan', The Guardian, 1 October 2008, available at <http://www.guardian.co.uk/business/2008/oct/01/bradfordbingley.creditcrunch> accessed 18 December 2008.

10 HM Treasury, 'Special Resolution Regime: Safeguards for Partial Property Transfers' (Cm 7497, 2008), p. 4.

11 Banking Act, s 11.

12 Ibid s 12.

13 Ibid s 13, 82 \& 83(3).
} 
The FSA's principal duty is to judge whether the bank has breached, or is likely to breach, its regulatory 'threshold conditions', and that it is not reasonably likely that any other action taken will enable the bank to satisfy the 'threshold conditions'. The Treasury retains control of any decisions involving the commitment of public funds.

The second reform of the Banking Act deals with the funding of the Financial Services Compensation Scheme (FSCS), which acquires wider powers and becomes a pre-funded scheme. The third important reform introduced by the Act is the addition to BoE's remit of a financial stability objective and the establishment of a Financial Stability Committee within the BoE. Furthermore, the Act grants immunity to the BoE in the discharge of its functions as a Monetary Authority and formalizes the Bank of England's role in the oversight of inter-bank payment systems. Finally, it overhauls the laws governing the issue of banknotes in Scotland and Northern Ireland, limits their issuance to existing issuers, and provides for new reserve requirements.

This article identifies the regulatory weaknesses exposed by the Northern Rock crisis, which the Act seeks to address. In this mode, it provides a critical analysis of the main reforms introduced by the Banking Act 2009, and identifies the governance challenges to which the exercise of the SRR powers shall give rise. The article argues that the effectiveness of the SRR could be seriously undermined by flawed regulatory structures that also create issues of regulatory standing and legitimacy. Thus, the introduction of the Banking Act's SSR must be followed by a re-opening of the debate regarding the institutional structures of UK banking supervision and appropriate regulatory techniques. ${ }^{14}$

The article is divided in six sections. The first section is the present introduction. The second section provides an analysis of the Northern Rock crisis and identified regulatory failures. The third section provides an analytical and critical exposition of the main aspects of the SRR. The fourth section discusses the other important regulatory reforms introduced by the Act. The fifth section discusses the criticism that has been directed at various aspects of the proposed SRR. It argues that the strong distributional aspects of the SRR and the governance challenges it creates signal an urgent need to reconsider UK banking supervision structures. The sixth section brings the different strands of the discussion to a comprehensive conclusion.

\section{The Northern Rock crisis and regulatory failure}

\subsection{The liquidity crunch and Northern Rock's business plan}

From 1996 to 2007 global credit markets experienced a rapid expansion due to a combination of benign macro-economic conditions and expansive monetary policies based on low and relatively stable long-term interest rates. At the same time, market forces resorted to excessive use of financial innovation for the laying off of credit risk. Financial innovation mainly took the form of spreading and disseminating widely credit

14 For a comprehensive critique of risk-based regulation see J Gray, 'Is it Time to Highlight the Limits of Risk-Based Financial Regulation' (2009) 4 CMLJ 50-62. 
risk through the use of the 'originate and distribute' model, other structured finance techniques, and the use of credit derivatives, mainly credit default swaps (CDS). Through the use of securitization and of other structured finance techniques, banks were allowed to recycle income from their assets in order to facilitate ever more bank lending and asset acquisition. This in the process both increased the profit margins of credit institutions and their financial leverage. ${ }^{15}$

Excessive liquidity eventually led to the creation of an asset bubble primarily in the housing markets of the USA, the UK and of certain European countries such as Spain. ${ }^{16}$ The trigger of the present crisis was the mounting losses of US and European banks in the US market for sub-prime mortgages in the summer of 2007. These led to fears about the robustness of big bank balance sheets, the credibility of credit ratings and doubts about the limits of financial innovation. As a result, global credit markets came to a standstill in mid-July 2007. All big sources of funding for global banks—-the interbank market, retail deposits and the market for structured credit products—suddenly dried up. The liquidity problems encountered by US and European banks raised eventually solvency concerns which escalated to such a degree as to develop into a full blown financial crisis in September and October 2008. Especially the collapse of Lehman Brothers was interpreted by global markets as a revocation on behalf of the US government of the implicit and unjustifiable pledge that all banks were too big to fail and none as a result would be allowed to go under. In the ensuing weeks global markets went into a selling frenzy pushing the prices of financial assets, including bank stocks, into a massive downward spiral. This was further reinforced by the rapid deleveraging of the financial system that necessitated additional asset sales, ${ }^{17}$ and threatened the foundations of domestic and global financial systems. In fact, without the public interventions in the form of very costly rescue packages, there is little doubt that at least the western financial system would not have survived.

The global financial crisis has already claimed as victims some of the biggest US investment banks (Bear Stearns, Lehman Brothers, Merrill Lynch), which either failed or lost their independence, and the two biggest US mortgage providers, so-called Fannie Mae and Freddie Mac. Yet the first casualty was Northern Rock, a medium-sized UK mortgage provider. Formerly a building society, Northern Rock was a rapidly developing medium-sized bank which had its business base in North East England. To many, Northern Rock was the embodiment of the enterprising, innovative and socially conscious spirit of the people of the North East. However, on 13 September 2007 the dream of developing a major financial services player in the North East came to an abrupt

15 For an extensive analysis of the rational choice and behavioural causes of the global financial crisis, see E Avgouleas, 'The Global Credit Crisis, Behavioural Finance, and Financial Regulation: In Search of a New Orthodoxy' (2009) 9 Journal of Corporate Law Studies 121-157.

16 See, inter alia, 'Sub-prime and banking crisis: Who caused this nightmare? The blame spreads' The Times (19 March 2008) $<\mathrm{http}$ //businesStimesonline.co.uk/tol/business/industry_sectors/banking_and_finance/article3579171.ece> accessed 21 December 2008.

17 See Bank of England, 'Financial Stability Report', October 2008, Issue 24 and IMF, Global Financial Stability Report, 'Financial Stress and Deleveraging, Macrofinancial Implications and Policy', October 2008, 9-19. 
and shattering end. In the previous month Northern Rock had found itself unable to fund its obligations following the virtual freeze of wholesale bank markets. ${ }^{18}$ Although, the market disruption did not affect Northern Rock's existing securitizations, the market for new securitizations had largely closed. In addition, while the market disruption did not lead to a cessation of Northern Rock's wholesale funding, it greatly affected its duration (shorter maturities) and cost (much higher interest rates).

The combination of these factors led the Northern Rock Board to seek assurance that contingency funding from the Bank of England would be available. Such assurance was, in effect, denied. As panic spread on 12 and 13 September 2007 savers flocked to the bank's branches in an attempt to rescue their savings, pushing the bank into further trouble. The image of panicking savers forced the UK authorities to launch a full blown rescue through loans extended by the BoE to the Northern Rock and eventually by bringing the bank into public ownership.

The last bank panic in England occurred in 1866. The collapse of the recklessly managed Overend Guerney and the Bank of England's inability/unwillingness ${ }^{19}$ to intervene triggered a generalized banking run. The last run in Scotland took place in $1878 .^{20}$ In the intervening years and up until September 2007 Britain participated in and won two World Wars, became a member of the EU, entered and left the European Monetary System, ceased being an imperial power and experienced several economic upheavals, including a spate of nationalizations that was followed in the Thatcher years by a wave of privatizations. Yet there was no depositors' run. Even the cataclysmic events of September/October 2008 which wiped out the US investment banking industry and brought to the brink of collapse the UK's banking system did not trigger a major depositors' panic, possibly because the UK Authorities had by then learnt their lesson. Therefore, the Northern Rock crisis, though not unique in its causes or scale, was a watershed moment for the UK's system of banking supervision and financial stability and for that reason it merits special consideration.

\subsection{Regulatory failure}

\subsubsection{Failure of supervision}

The handling of the crisis by the FSA drew ferocious criticism by Parliament. The House of Commons Committee accused the FSA of having systematically failed in its duty to supervise Northern Rock. ${ }^{21}$ All evidence points to the fact that the FSA should have

18 The Run on the Rock, 35-36.

19 Although the BoE's inertia attracted the wrath of the biggest thinker of his era, a certain Walter Bagehot, it seems that the BoE, which was a plc owned by its shareholders, was right that its corporate charter did not allow it to rescue Overend Guerney. See W Bagehot, Lombard Street: A Description of the Money Market (Henry S King \& Co., London 1873) and G Elliott, The Mystery of Overend \& Gurney: A Financial Scandal in Victorian London (Methuen Publishing Ltd, London 2006). However, the fact that Overend Gurney was before its collapse the biggest bank in the country after the BoE means that corporate rivalry may not be ruled out when it comes to explaining BoE's stance.

20 In general, Scottish banks were considered sound commercial operations, because they pursued successful and stringent lending policies, although the Scottish banking system did not have a Lender of Last Resort.

21 In specific, the Committee said in its Report: 'In the case of Northern Rock, the FSA appears to have systematically failed in its duty as a regulator to ensure Northern Rock would not pose such a systemic risk, and this failure contributed significantly to the difficulties, and risks to the public purse, that have followed.' The Run on the Rock, 34 (para. 66). 
questioned Northern Rock about the financial viability of its business plan with its reliance on wholesale markets for funding its business. The Governor of the BoE testifying in the Treasury Committee expressed the view that Northern Rock's business strategy of relying for funding on the wholesale banking markets was 'fatally flawed', as once those closed the bank was totally 'unable to finance [its] totally illiquid assets'. ${ }^{22}$

Another indication of the FSA's deteriorating financial state and performance that the FSA failed to pick up and follow was the continuous decline of Northern Rock's share price in a rising stock market. ${ }^{23}$ Yet the FSA, though aware of the liquidity issues raised by the bank's business model, failed to act. While Northern Rock was in the FSA's list of high impact banks under continuous supervision, which are usually subjected to the Advanced, Risk-Responsive Operating Framework (ARROW) examination, ${ }^{24}$ Northern Rock was not scheduled to have another ARROW impact assessment, after the one in late 2005, until January 2009. It is hard to see how the FSA's duty of continuous supervision of banks was served with such an extensive time window for a thorough inspection of a highly leveraged bank such as Northern Rock. ${ }^{25}$

Things became worse when the FSA approved Northern Rock's application for the Basle II waiver on 29 June 2007. Obviously, Northern Rock, a bank that would soon find itself on the brink of collapse triggering a public rescue had, according to its calculations, which were approved by the FSA, excess (regulatory) capital. Thus, in a move indicative of their attitude towards robust financial management, the bank's board felt that some of its ('spare') capital had to be returned to its shareholders increasing the interim dividend by $30.3 \%$ and correspondingly weakening the bank's balance sheet while the threatening clouds of the gathering global liquidity crisis were already on the horizon! ${ }^{26}$ Arguably, Northern Rock's main problem was illiquidity. However, subsequent events proved that the bank's assets were not of the high quality previously thought and in fact some of them were either loss-making or non-performing and a higher capital cushion was necessary.

Perhaps the most damning assessment of the FSA's failure to effectively supervise Northern Rock was given by Professor Wood who said to the Treasury Select Committee: ${ }^{27}$

The FSA ... was asleep on the job; that is manifestly right. A very clear signal of a bank running a big risk is rapid expansion. Northern Rock was giving that signal quite clearly; it really is remarkable that [the FSA] missed it.

22 Ibid 18.

23 Northern Rock's share price moved from around 12 GBP to under 8 GBP between January and August 2007, while the stock of other financial sector firms kept rising. Ibid 23-24.

24 The FSA is a risk-based regulator and ARROW is the framework they use to make risk-based regulation operational. The ARROW framework has three main components: (i) ARROW Firms: used when assessing risks in individual firms; (ii) ARROW Themes: used when assessing cross-cutting risks, i.e. those involving several firms or relating to the market as a whole, and Internal Risk Management: used when assessing the operational risks that might impact the FSA. See FSA, 'The FSA's Risk-Assessment Framework', August 2006, 2.

25 The Run on the Rock, 21.

26 Ibid 24-25.

27 Ibid 22. 
For months the FSA publicly defended its actions and given very little ground to the fierce criticism it has suffered from all quarters, including the Report of the Parliamentary Committee. However, in private the picture was much different. Most employees involved in the supervision of Northern Rock have now left the regulator. ${ }^{28}$

The FSA Internal Audit Report has shaken the organization. ${ }^{29}$ The Internal Audit review identified the following four key failings specifically in the case of Northern Rock: $:^{30}$

(a) Lack of sufficient supervisory engagement with the firm, in particular the failure of the supervisory team to follow up rigorously with the management of the firm on the business model vulnerability arising from changing market conditions,

(b) Lack of adequate oversight and review by FSA line management of the quality, intensity and rigour of the firm's supervision,

(c) Inadequate resources specifically dedicated to the direct supervision the firm,

(d) Lack of intensity by the FSA in ensuring that all available risk information was properly utilized to inform its supervisory actions.

However, the review concluded that, overall, the flawed approach to the supervision of Northern Rock did not reflect 'the general practice of supervision of high-impact firms at the FSA'. ${ }^{31}$ In response to the recommendations made in this review, ${ }^{32}$ the FSA announced details of a supervisory enhancement programme, which included five key actions: ${ }^{33}$ (a) increased senior management engagement with high-impact firms, (b) increased focus on prudential supervision, including liquidity and stress testing, (c) increased numbers of supervisory staff engaged with high impact firms, (d) the creation of a new group of supervisory specialists and (e) improved use of information and intelligence.

Yet are things so simple? Is the Northern Rock collapse a mere case of regulatory inertia or incompetence, or as the FSA say an example of inadequate application of sound supervisory principles? It has already been argued that something more serious happened directly linked to the inadequacies of the risk-based regulation. ${ }^{34}$ Also, I suggest, in section 5 below, that the fact that the same authority, the FSA, is both market conduct/ conduct of business and consumer protection regulator of financial services firms and

\footnotetext{
28 Another alleged outcome of the Northern Rock crisis was the premature departure of Sir John Gieves, the Bank's deputy governor in charge of financial stability, who came in for some ferocious criticism in Parliament's Report. See S Kennedy and Grainne Gilmore, 'Gieve in Unexpected Exit as Deputy Governor of the Bank of England', The Times, 19 June $2008,42$.

29 In October 2007 the Chief Executive of the FSA asked the FSA's director of internal audit to carry out a lessons learned review of the supervision of Northern Rock plc during the period 1 January 2005 to 9 August 2007. FSA, Internal Audit Division Report, 'The Supervision of Northern Rock: A Lessons Learned Review', March 2008, available at <http://www.fsa.gov.uk/pubs/other/ nr_report.pdf $>$ accessed 26 February 2009.

30 Ibid 6-9.

31 Ibid 9.

32 Ibid 9-11.

33 See FSA Press Release, 'FSA Moves to Enhance Supervision in Wake of Northern Rock', FSA/PN/028/2008 (26 March 2008) <http://www.fsa.gov.uk/pages/Library/Communication/PR/2008/028.shtml> accessed 20 December 2008.

34 Gray, The Limits of Risk-based Financial Regulation, n 14.
} 
the overseer of their compliance with systemic stability regulations makes the proper discharge of its functions very difficult.

\subsubsection{The rationales for liquidity support and liquidity regulation}

\section{a. Liquidity support and moral hazard: it's a king's dilemma}

The BoE was in the weeks before the Northern Rock debacle, the biggest sceptic among G7 central banks of any public intervention in the crisis, because it would increase moral hazard. As a result, the BoE alone among all major central banks kept advocating high interest rates and the posting of conventional collateral for central bank lending to commercial banks well after the scale of the crisis had become apparent, at least to insiders, and the interbank credit market had all but dried up.

In the immediate aftermath of Northern Rock's collapse the Governor's hesitation to relax the BoE's requirements of eligible collateral in order to provide Northern Rock and other British banks with an injection of funds was heavily criticized. ${ }^{35}$ Eventually, the BoE responding to pressure coming from the Treasury and the British banking industry relaxed considerably its eligible collateral requirements, ${ }^{36}$ a policy that had already been followed by the US Federal Reserve and the ECB.

With the benefit of hindsight it can be said that the Governor underestimated the impact of psychology on the market and especially the reaction of depositors. Also, probably the Governor's principled approach to moral hazard was not the most appropriate one at a time of an unprecedented global credit crunch. Yet much of the criticism of the BoE's actions in this area is unfounded. In the absence of an outright rescue operation the required liquidity injection might have averted a depositors' run but it would not have saved Northern Rock.

First, as suggested by the Governor of BoE and confirmed, in the hearings of the Parliamentary Committee, by the Chancellor and Professors Buiter and Wood, both among the fiercest critics of the BoE's handling of the crisis, a relaxation of the BoE's requirements for the use of its liquidity facility would not have saved Northern Rock. In the absence of a gigantic liquidity injection to the markets by the BoE to bring the wholesale banking markets to their pre-July 2007 liquidity levels, Northern Rock would have failed in any case, because of its reliance for funding on those markets. ${ }^{37}$ Therefore, its collapse was much more the result of its flawed business model and of inadequate deposit insurance cover and much less, if at all, to the BoE's unwillingness to give it a significant liquidity injection.

Second, the provision of additional central bank liquidity against a wider range of collateral and over longer periods in order to reduce market interest rates at longer maturities is not a simple issue and any relevant decision has to take into account two

35 Professor Buiter noted in his testimony before the Parliamentary Committee the BoE's insistence to discount already liquid collateral, eg, government securities, offering essentially maturity transformation fell short of what was really required, which was liquidity transformation, i.e., the bank taking illiquid collateral such mortgages in exchange of liquid ones. The Run on the Rock, 42. 36 Special Liquidity Scheme: Market Notice (The Bank of England, 21 April 2008).

37 The Run on the Rock, 44-46. 
conflicting considerations. While, the provision of greater short-term liquidity against illiquid collateral reduces term market interest rates, it also undermines the efficient pricing of risk. Essentially, it provides ex post insurance for risky behaviour providing a perverse incentive to bank management to behave irresponsibly, namely, it creates moral hazard. As a result, liquidity support encourages excessive risk-taking and thus it plants the seeds of a future financial crisis. On the other hand, as has been noted by many commentators, and the FSA, support operations should be conducted to ensure that the financial system continues to function effectively, given also 'pivotal position of banks in the financial system, especially in clearing and payments systems [and the] potential systemic dangers resulting from bank runs'. ${ }^{38}$ In fact, this is the reason that subsequently, the BoE, either in the context of the Special Liquidity Scheme or under other facilities, injected gigantic sums of money to UK banks.

\section{b. Liquidity regulation}

Another cause of supervisory failure in the case of Northern Rock, and across the board with respect to the many banks that became deeply embroiled in the global financial crisis, was the lack of adequate liquidity regulation. This was less the FSA's or BoE's fault and more the result of a nearly obsessive global focus on bank capital adequacy at the expense of imposing minimum standards of liquidity. However, given that liquidity crises are much more frequent than is generally thought, the loophole was virtually inexcusable. ${ }^{39}$ The Governor of the BoE said before the Parliamentary Committee: ${ }^{40}$

If we had a system of proper liquidity regulation, although Northern Rock would have shown up as doing very well on the capital side, it would have looked very flawed on the liquidity side, and that would have been picked up.

In fact, it was convincingly argued before the Parliamentary Committee that had Northern Rock not changed its status from Building Society to a Bank through demutualization, it could not have been as successful in terms of financial returns but it would also not have to face the liquidity problems it encountered because Building Societies were obliged to hold a high percentage of liquid assets as a ratio over their liabilities and thus do not rely to the same extent on wholesale funding. ${ }^{41}$

The value to the health of the banking system of minimum liquidity requirements for banks has been proved beyond doubt in the course of the global financial crisis. As has already been noted by the FSA, 'regulation of liquidity risk is particularly warranted, as the social costs of the failure of a financial institutions often exceed the private costs, and the social costs are not fully incorporated into decision-making processes by firms' ${ }^{42}$ In a rather responsive way the FSA is currently consulting on a new liquidity regulation regime for UK banks, based on the new liquidity standards devised by the Basel

38 FSA, 'Strengthening Liquidity Standards', Consultation Paper 08/22, December 2008, 13.

39 Ibid Annex 4.

40 The Run on the Rock, 27.

41 Ibid 27-8.

42 FSA, n 38, and D. Llewellyn, 'The Economic Rationale for Financial Regulation', FSA, Occasional Paper 1, April 1999. 
Committee on Banking Supervision. ${ }^{43}$ The new regime will oblige UK-based banks to comply, inter alia, with minimum liquidity requirements, so-called Liquidity Adequacy Standards. ${ }^{44}$

\section{c. Delayed disclosure of liquidity support and the market abuse directive}

The Governor of the BoE blamed the EU Market Abuse Directive (MAD) ${ }^{45}$ for preventing the BoE from conducting a covert liquidity support operation for Northern Rock, which would have enabled it to avoid a very public depositor's run. ${ }^{46}$ In specific, the BoE received legal advice that the covert operation had to be disclosed under Article 6(1) of MAD (duty of continuous disclosure of inside information), because it could not benefit from the 'legitimate interests' safe harbour of 6(2) of $\mathrm{MAD},{ }^{47}$ as implemented in the UK. The accuracy of this advice was subsequently strongly disputed. It should be noted here that, as the author is aware, Market Abuse legislation was also a thorny issue with respect to covert liquidity support operations directed to ailing credit institutions by other EU central banks in the course of 2008.

However, both in the UK and in several other EU jurisdictions the problem was less with the wording of the Directive in Article 6(2), which is rather ambiguous on this point, and more with national implementation of MAD. For instance, FSA guidance interpreting Rule 2.5.3R of the FSA Disclosure and Transparency Rules (DTR), the UK implementing law, on the application of Articles 6(1) and (2) MAD and Article 3 of Directive 2003/124/EC ${ }^{48}$ (the Level 2 Directive implementing certain parts of MAD), was very restrictive. ${ }^{49}$ While Article 3 of Directive 2003/124/EC clearly states that the grounds enumerated therein for delaying the publication of inside information by an issuer of securities are only indicative, DTR 2.5.5G, containing FSA guidance, rules out the possibility of the existence of any other grounds justifying such delay, other than those enumerated in DTR 2.5.3, although the latter explicitly provides that its list is non-exhaustive.

The FSA has now amended the DTR, inserting DTR 2.5.5A $\mathrm{R},{ }^{50}$ which grants the 'legitimate interest' safe harbour to issuers receiving liquidity support by the BoE or other Central Bank. Arguably, an even wider safe harbour would be closer to the letter and the

43 Basel Committee on Banking Supervision, 'Principles for Sound Liquidity Risk Management and Supervision', September 2008.

44 FSA, Strengthening Liquidity Standards, n 29. See also FSA, 'Review of the Liquidity Requirements for Banks and Building Societies', Discussion Paper 07/07, December 2007.

45 Directive 2003/6/EC on Insider Dealing and Market Manipulation (market Abuse) [2003] OJ L96/16. On the ambit of Article 6 of MAD, see E Avgouleas, The Mechanics and Regulation of Market Abuse, A Legal and Economic Analysis (OUP, Oxford 2005), 2635.

46 The Run on the Rock, 57.

47 Article 6(2) of MAD provides: 'An issuer may under his own responsibility delay the public disclosure of inside information, as referred to in paragraph 1 , such as not to prejudice his legitimate interests provided that such omission would not be likely to mislead the public and provided that the issuer is able to ensure the confidentiality of that information.' (Emphasis added).

48 Directive 2003/124/EC of 22 December 2003 implementing Directive 2003/6/EC as regards the definition and public disclosure of inside information and the definition of market manipulation [2003] OJ L339/70.

49 This argument is reinforced by the view expressed by Commission officials to the Treasury committee members that the FSA and the BoE could have used the safe harbour given under Article 3 Directive 2003/124/EC. The Run on the Rock, 59.

50 The introduction by the FSA of the new rule followed the publication of FSA, 'Discosure of Liquidity Support', CP 08/13, July 2008 and attendant consultation. 
spirit of the MAD. Namely, the same safe harbour could be given to issuers under all circumstances, where there is superior public interest (eg in order not to trigger a depositors' run or a market panic), which justifies inside information to remain undisclosed, for a short period of time, in spite of the danger of creating a false market. In such a case, the FSA should be given the power of opinion/approval as to the necessity of delayed publication of inside information.

\section{The SRR}

\subsection{Institutional structure and the objectives of SRR}

\subsubsection{Structure}

The Treasury, the BoE and the FSA (hereinafter relevant authorities) are given the power to resort to one of the three options granted to them under the new SRR, namely, to use their stabilization powers or initiate bank insolvency or bank administration procedures in order to address a 'situation where all or part of the business of a bank has encountered, or is likely to encounter, financial difficulties'. ${ }^{51}$ In practice, any decision to trigger the SRR and to deploy one or more of the tools within it, would only be taken following intensive discussion and consultation between the Treasury, the Bank of England and the FSA. Nevertheless, for reasons of accountability, the Treasury finds it important to clarify in the Act the lead responsibility of each institution based on their mandate and expertise:

(a) the FSA for supervisory decisions and regulatory actions, including the ongoing supervision of any firm while it continues to operate in the SRR;

(b) the Bank of England for liquidity support and operation of the SSR;

(c) the Treasury for decisions having an impact on public finances, concerning compliance with the UK's international obligations and the overall public interest;

(d) the Financial Services Compensation Scheme (FSCS) for delivering the payment of compensation and assessing the readiness of a bank to payout of its depositors.

\subsubsection{The objectives of the SRR}

The exercise of the SSR tools by the relevant authorities shall be pursuant to the following set of objectives (SRR Objectives): ${ }^{52}$

(a) the protection and enhancement of the stability of the UK financial system;

(b) the protection and enhancement of public confidence in the stability of the UK banking system;

(c) depositor protection;

51 Under S 10 of the Banking Act, for any Orders the Treasury will issue under the SRR (excluding the stabilization powers, compensation scheme orders, resolution fund orders and third party compensation orders) will have to consult a new Banking Liaison Panel, which will include: (a) a member appointed by the Treasury, (b) a member appointed by the BoE, (c) a member appointed by the FSA, (d) a member appointed by the scheme manager of the FSCS, (e) one or more persons who in the Treasury's opinion represent the interests of banks. Also the Panel will include legal experts in the law relating to the UK financial system of the United Kingdom, and experts in insolvency law and practice.

$52 \mathrm{~S} 4$. 
(d) the protection of public funds;

(e) avoidance of any interference with property rights in contravention of a Convention right (within the meaning of the Human Rights Act 1998).

Each of the objectives is to be considered by the relevant authorities 'as appropriate' on a case-by-case basis and they are not set out in a hierarchical order. The use of the stabilization powers, the bank insolvency procedure and the bank administration procedure, shall be governed by a Code of Practice issued by the Treasury. In specific, the Code will provide guidance on: (a) how to achieve the SRR objectives, (b) the information to be provided in the course of a consultation under the SRR, (c) the giving of advice by one relevant authority to another about whether, when and how the stabilization powers are to be used, (d) how to determine whether Condition 2 in Section 7 of the Act is met (see section 3.2.1 below), (e) how to determine whether the conditions for the use of stabilization powers are satisfied and ( $f$ ) the management and control of bridge banks, including arrangements for management and control at different stages, and eventual disposal, (h) prescribing the way banks taken into temporary public ownership under the SSR shall be managed. Responding to considerable industry and political pressure and concern as to how the relevant authorities will use their SRR powers, the Treasury issued a draft Code setting out the main guidelines as part of their November 2008 Consultation Paper on Safeguards for the Partial Transfer of Property under the SRR. ${ }^{53}$ The Code shall be finalized, once the Act has been endorsed by Parliament.

\subsection{Requirements for the exercise of stabilization powers and of stabilization options}

\subsubsection{Conditions for the exercise of stabilization powers}

A set of general conditions applies to the exercise of stabilization powers. ${ }^{54}$ In specific, the FSA must be satisfied that, in the absence of any financial assistance provided by the Treasury, or the Bank of England (disregarding ordinary market assistance offered by the BoE on its usual terms), the following General Conditions are met:

(a) Condition 1: the bank is failing, or is likely to fail, to satisfy the threshold conditions (within the meaning of Section 41(1) of the Financial Services and Markets Act 2000 (permission to carry on regulated activities)),

(b) Condition 2: having regard to timing and other relevant circumstances it is not reasonably likely that action, other than exercising the stabilization powers, will be taken by or in respect of the bank that will enable the bank to satisfy the threshold conditions.

Before determining whether or not Condition 2 is met the FSA must consult the Bank of England, and the Treasury but need not consider the SRR Objectives. Essentially the

53 See n 10 above, Annex C [Hereinafter the draft Code].

54 Banking Act, S 7. 
General Conditions mean that the FSA, as the bank's supervisor carries an assessment of the financial state of the bank. If it deems it to have failed (or is likely imminently to fail) to meet the threshold conditions of FSMA section 41(1) and alternative options to remedy the situation through voluntary actions and regulatory intervention are unlikely to be sufficient to bring it in compliance with the threshold conditions in the near future, ${ }^{55}$ then the BoE or the Treasury may proceed exercising their SRR powers. In addition, to the General Conditions, there are also Specific Conditions that must be met for the BoE to exercise its stabilization powers.

Furthermore, under Section 8 of the Act, for the first two stabilization options: private sector purchaser and bridge bank (Sections 11(2) and 12(2)) the BoE may exercise its powers only if it is satisfied that the following two specific conditions are met:

Condition A: the exercise of the power is necessary by reference to the public interest in (a) the stability of the UK financial system, (b) the maintenance of public confidence in the stability of the UK banking system, or (c) the protection of depositors. Before determining whether Condition $A$ is met, and if so how to act, the BoE must consult the FSA, and the Treasury. Where the Treasury has notified the BoE that they have provided financial assistance to a bank for the purpose of resolving or reducing a serious threat to the stability of the UK financial system, then the FSA may exercise its stabilization powers with respect to a private sector purchaser and bridge bank options only where the second specific condition (Condition B), instead of Condition A, is satisfied.

Condition $B$ is that: (a) the Treasury have recommended the BoE to exercise their stabilization powers on the grounds that it is necessary to protect the public interest and (b) in the Bank's opinion, exercise of the stabilization power is an appropriate way to provide the required protection.

According to the Treasury's draft Code the 'test of "necessity" is a high one' and the 'assessment must balance the short and long-term effects on financial stability, public confidence and depositor protection of different resolution options'. ${ }^{56}$ Furthermore, when considering the need to protect depositors, the BoE will take into account not only the implications of losses but also the consequences of lack of access to deposits. In fact, at times of heightened systemic risk, similar to those experienced by the UK banking system in September and October 2008, apart from the need to protect retail depositors, the protection of business and other wholesale depositors of a failing institution acquires increasing importance. ${ }^{57}$

With respect to the option of passing a bank in distress or the 'holding company' of a bank into temporary public ownership under Section 13(2) of the Act, the Treasury before exercising its stabilization powers must be satisfied, following consultation with the FSA and the BoE, that two specific conditions set out in Section 9 of the Act are met. The first of the special conditions (Condition $\mathrm{A}$ ) is that the exercise of the power is necessary to resolve or reduce a serious threat to the stability of the financial systems of the United Kingdom. The second condition (Condition B) is that exercise of the power is necessary to protect the public interest, where the Treasury have provided financial assistance in

$55 \mathrm{Cl} 24$ of the draft Code, n 53.

$56 \mathrm{Cl} 32$ of the draft Code.

57 Ibid cl. 33. 
respect of the bank for the purpose of resolving or reducing a serious threat to the stability of the UK financial system.

It should be noted here that, under Section 76, the BoE may not exercise a stabilization power in respect of a bank, if the Treasury notify the Bank that the exercise would be likely to contravene an international obligation undertaken by the UK. Also with respect to the bridge bank option, the BoE may be required by Treasury notice to take a specific action, or abstain from taking a specific action, in order to comply with the UK's International obligations (Section 77).

Finally, as the role of the Treasury here is to oversee any decision that involves public funds, not only taking an institution into temporary public ownership falls within its own prerogative, but also the exercise of any stabilization power with respect to the other two stabilization options is made subject to Treasury's consent, under Section 78, especially if compensation may be payable. ${ }^{58}$ Under Section $78(4)$, if Treasury's consent is refused, because the exercise of a stabilization power has implications for public funds, the BoE must consider ways of exercising its stabilization powers in a way that meets the SRR Objectives and avoids the Treasury's objections.

\subsubsection{Stabilization options}

\section{a. Scope and general requirements}

The SRR stabilization options may only be exercised in respect of UK incorporated deposit taking institutions, ${ }^{59}$ and subject to modifications, to UK based building societies. ${ }^{60}$ Also, the Act gives the power to the Treasury to extend the application of the SRR stabilization options to credit unions. ${ }^{61}$

Once the public interest test is met and the BoE or the Treasury determine that it is necessary to exercise one of the SRR tools with respect to a bank, they will need to consider which of the tools it should use to achieve the best result possible and whether use of the tool would be compatible with their legal obligations (including its obligations under international law). ${ }^{62}$ A crucial factor in their decision should be information they have regarding the state of the balance sheet and operations of the bank concerned and the known interests of third parties. ${ }^{63}$

The Act does not rank hierarchically the three different stabilization options, despite calls by the conservative opposition to give explicit precedence to private sector transfers. ${ }^{64}$ However, the SRR exhibits a strong implicit bias towards such a solution. Thus, the Treasury's draft Code provides that the other issues that the BoE will need to consider in determining the feasibility of different stabilization tools include: ${ }^{65}$ (a) the

58 Ibid cl 39.

59 Banking Act 2009, S 2.

$60 \mathrm{~S} 84$.

$61 \mathrm{~S} 89$.

$62 \mathrm{Cl} 34$ of the draft Code.

63 Ibid cl 35.

64 Eg Mark Hoban, MP (Shadow Minister, Treasury), Hansard HC Vol 483 col 813 (26 November 2008).

$65 \mathrm{Cl} 36$ of the draft Code. 
existence of, or likelihood of finding, a private sector purchaser, (b) the likely saleability of assets and liabilities of the failing bank or building society, including whether a whole bank or building society sale is viable, and whether this would minimize the cost to the public finances, (c) the likely speed of FSCS payout to eligible depositors, and the method by which this would be achieved, (d) the feasibility of adopting a partial solution, (such as the exercise of the partial transfer option), (e) the operational risks of managing a bridge bank and the amount of public funding that may be required to keep it operational.

\section{b. Private sector purchaser}

Under Section 11 of the Act the first stabilization option is to sell all or part of the business of the bank to a commercial purchaser. For that purpose the BoE may issue (i) one or more share transfer instruments and/or (ii) one or more property transfer instruments.

A share transfer instrument is an instrument which: (a) provides for securities issued by a specified bank to be transferred and (b) makes other provision for the purposes of, or in connection with, the transfer of securities issued by a specified bank. ${ }^{66}$ As soon as is reasonably practicable after making a share transfer instrument in respect of a bank, the BoE must notify the other relevant authorities, the bank concerned and other interested parties and publish a copy on its website and two newspapers of its choice. ${ }^{67}$

A share transfer order is an order which: (a) provides for securities issued by a specified bank to be transferred; (b) makes other provision for the purposes of, or in connection with, the transfer of securities issued by a specified bank. ${ }^{68}$ Share transfer orders shall be made by statutory instrument, and shall be subject to annulment in pursuance of a resolution of either House of Parliament. ${ }^{69}$

The term 'securities' is given an unusually broad definition and includes: ${ }^{70}$ (a) shares and stock (Class 1), (b) debentures (Class 2) including (i) debenture stock, (ii) loan stock, (iii) bonds, (iv) certificates of deposit and (v) any other instrument creating or acknowledging a debt, (c) warrants or other instruments (Class 3 ) that entitle the holder to acquire anything in Class 1 or 2, (d) rights (Class 4) which (i) are granted by a deposittaker and (ii) form part of the deposit-taker's own funds for the purposes of Directive 2006/48/EC (on the taking up and pursuit of the business of credit institutions).

Director Removal (Section 20): Share transfer instruments and orders may respectively enable the Bank of England and Treasury: (a) to remove a director of a specified bank, or of a 'holding company' brought into TPO by virtue of Sections 82 and 83, (b) to vary the service contract of a director of a specified bank, or of a 'holding company', (c) to terminate the service contract of a director of a specified bank, or of a 'holding company', (d) to appoint a director of a specified bank, or of a 'holding company'. This provision

66 Banking Act 2009, s 15.

67 S 24.

68 S 16.

$69 \mathrm{~S} 25$.

70 S 14. 
has also attracted opposition from the industry. However, such opposition is unjustifiable. This power is necessary as the BoE or the Treasury will certainly want a 'clean break' from the previous regime that failed the specific bank's shareholders and creditors, and the public will want to see some sort of 'punishment' imposed on the failing bank directors. Certainly it is expected to be exercised immediately after the transfer of the bank, in order to bring immediate 'catharsis' to the public sphere.

A property transfer instrument is an instrument which: (a) provides for property, rights or liabilities of a specified bank to be transferred, (b) makes other provision for the purposes of, or in connection with, the transfer of property, rights or liabilities of a specified bank. ${ }^{71}$ Such instrument may relate to total or partial transfers of property, rights and liabilities of a specified bank. ${ }^{72}$

In the case of a share transfer or property transfer to a private sector purchaser under Section 11(2), the Treasury shall make a compensation scheme order, ${ }^{73}$ which may make provision for third party (ie a party other than the transferor) compensation. ${ }^{74}$ Provision for third party compensation is mandatory only in the case of a partial property transfer. ${ }^{75}$ As a result, in the case of share transfers or of transfers of the entire property involved, third party holders of lesser rights/interests in shares and debentures, including as security, rights under a trust or option to buy securities may lose their rights without receiving compensation.

Moreover, a compensation scheme order may provide for the amount of any compensation payable to be determined by an independent valuer ${ }^{76}$ and specify principles (valuation principles) to be applied in determining the amount of compensation. ${ }^{77}$ The Treasury may make regulations about third party compensation arrangements in the case of partial property transfers under the stabilization options. ${ }^{78}$ The regulations shall provide, inter alia, the conditions under which compensation is paid and the amount payable determined by reference to specified factors. ${ }^{79}$

The three most important and problematic aspects of the SRR with respect to transfers of property, rights and liabilities of a specified bank by means of property transfer instruments are: (a) partial transfers, (b) that they take effect 'despite any restriction arising by virtue of contract or legislation or in any other way', ${ }^{80}$ and (c) that the effects extend to transfers of foreign property. As restriction is defined here: (a) any assignability or transferability restriction, including lack of capacity, whether this is of a general nature

$71 \quad S 33$.

72 Ibid.

73 'A "compensation scheme order" is an order-(a) establishing a scheme for determining whether transferors should be paid compensation, or providing for transferors to be paid compensation, and (b) establishing a scheme for paying any compensation.' S 49(2).

74 Ss 50(1)-(3).

75 S 50(4).

76 S 54.

$77 \mathrm{~S} 57$.

$78 \mathrm{~S} 60$.

79 S 60(5).

80 S 34(3). 
or by reference to a particular person and (b) any legal, contractual or otherwise requirement of consent. As foreign property is defined: ${ }^{81}$ (a) property outside the United Kingdom and (b) rights and liabilities governed by foreign law. ${ }^{82}$

(i) Transfers of foreign property

Transfers of foreign property are capable of creating all kinds of conflict of laws implications. The Act (Section 39(3)) places a burden on the transferor and the transferee to take 'any necessary steps to ensure that the transfer is effective as a matter of foreign law (if it is not wholly effective by virtue of the property transfer instrument)'. The Act (Section 39(4)) recognizes that the transfer cannot be effective unless it is also valid under foreign law. Of course, given Parliament supremacy the SRR provisions with respect to property transfers, inspite of any legal or contractual restriction, will take effect in a rather unproblematic way in the UK, notwithstanding the many conflicts they will create with pre-existing property and contract law requirements for the transfer of property or of customer contracts, which are overridden by SRR. However, the same cannot be said of the extra-territorial effect of the property transfers under SRR, which are bound to prove very problematic and their application will give rise to waves of litigation in foreign jurisdictions. Thus, the ultimate force of transfers of 'foreign property' under the SRR will be judged by foreign courts, which are unlikely to deem their own property, contract and consumer protection laws, often based on their Parliaments' Statutes, subordinate to the SRR provisions. Thus, the transferor's and the transferee's efforts to contractually bypass such restrictions in accordance with their obligations under Section 39 may prove impossible or ineffective.

(ii) Partial transfers

The issue of partial transfers, where a failing bank is split and its good part is transferred to a private sector buyer, or a bridge bank (discussed in section 3.2.2(c) below), has given rise to a multitude of concerns. These mainly refer to the danger of unequal treatment of failing bank creditors, who would have been better off had the whole bank gone into an insolvency procedure, because of the possibility of cherry picking, and the disruptive effect of partial transfers on set off agreements and netting agreements and security interests. In fact, it was convincingly argued that the negative consequences which could flow from partial transfers would have negative implications for UK banks and financial markets, increasing their cost of funding and requirements for regulatory capital (where netting agreements are taken into account to lower levels of regulatory capital), ultimately leading UK banks to a loss of competitiveness. In response to these concerns the Treasury issued in November 2008 a Consultation Paper on Safeguards for Partial Property Transfers, which includes a draft Order that addresses most of those concerns. ${ }^{83}$ Section 48(2) of the Act gives the power to the Treasury to issue an Order which shall: (a) restrict the making of partial property transfers in cases that involve, or where they might affect,

81 S 39(2).

82 " "F $[F]$ oreign law" means the law of a country or territory outside the United Kingdom'. S 39(8).

83 See n 10. 
protected arrangements (defined here as security interests, title transfer collateral arrangements, set-off arrangements and netting arrangements); (b) impose conditions on the making of partial property transfers in cases that involve, or where they might affect, protected arrangements (c) require partial property transfers to include specified provision, or provision to a specified effect, in respect of or for purposes connected with protected arrangements; (d) provide for a partial property transfer to be void or voidable, or for other consequences (including automatic transfer of other property, rights or liabilities) to arise, if or in so far as the partial property transfer is made or purported to be made in contravention of a provision of the Treasury Order. Therefore, the draft Order protects relevant contracts/assets from partial transfers subject, however, to wide 'carve outs'.

Nonetheless, even this arrangement has attracted strong opposition from the industry, which requires the exclusion of set off and netting agreements from most of the 'carve outs' proposed in the draft Order, in order to avoid cherry-picking, legal uncertainty and unequal regulatory capital treatment. ${ }^{84}$ This position is, of course, reasonable, as it creates certainty of law in relevant financial transactions, especially as regards set off and netting arrangements which cover 'foreign property', 85 given also the possible conflict of laws issues which may arise in this context. However, industry's view is also impractical not only in the context of partial transfers under the SRR but also in the context of using, in a voluntary manner, a 'bad bank' facility in order to separate well performing from distressed bank assets.

(iii) Succession and Continuity

Two issues of utter importance with respect to transfers of property, other legal rights as well as service contracts, are those of succession and continuity. These are important not only with respect to the transfer of valid legal rights and liabilities protecting, on the one hand transferor and transferee interests, and creditor interests on the other. Continuity is also important with respect to the continuation of branch leases and of IT and other infrastructure service contracts, which are vital for the undisrupted operation, and essentially survival, of the transferred business. Section 36 makes provision to maintain continuity of legal relationships for property transfers effected under the stabilization options. As a result, a property transfer instrument may provide for a transfer to be, or to be treated as, a succession and for the transferee to be treated for any purpose connected with the transfer as the same person as the transferor. ${ }^{86}$ Also, it may provide for agreements made or other things done by or in relation to a transferor to be treated as made or done by or in relation to the transferee. ${ }^{87}$

A property transfer instrument may provide for legal proceedings and other issues that relate to anything transferred and is in the process of being done by or in relation to the

84 See BBA, 'Special Resolution Regime Safeguards for Partial Property Transfers-BBA Response to the HM Treasury Consultation Document', January 2009.

85 Ibid 2, para 6.

86 S 36(1).

87 S 36(2). 
transferor immediately before the transfer date, to be continued by or in relation to the transferee. ${ }^{88}$ It may also include provisions for the continuity of employment in relation to transferred contracts of employment. ${ }^{89}$ With respect to licences Section 37 provides that, '[a] licence in respect of anything transferred by property transfer instrument shall continue to have effect despite the transfer', unless it is stated in the property transfer instrument itself that this provision is dis-applied to a specified extent. Moreover, a property transfer instrument may apportion enforceable rights and liabilities that have been transferred between the transferor and the transferee to a specified extent and in a specified way. ${ }^{90}$

Another area of concern in the context of legal continuity is, of course, to prevent counter-parties (bank creditors) from calling share or property transfers effected under the SRR as 'events of default' in the context of loan agreements, bond issues or ISDA master agreements for the trading of derivatives, or agreements for securities lending. Thus, the Act makes an explicit provision that such agreements may not be terminated either by virtue of the relevant authorities exercising their powers under the SRR or by virtue of preliminary actions or decisions leading to an ultimate transfer of securities or property. $^{91}$

Finally, in the case of partial transfers it is possible that the transferred part of the business will rely on the residual bank or other companies within the same group for the supply of infrastructure, IT, payments, clearing and other services and facilities which are essential to the operation of the transferred bank. The BoE can by means of notice ask the 'residual bank and each group company [to] provide such services and facilities as are required to enable a transferee to operate the transferred business effectively' (the continuity obligation) subject to reasonable consideration. ${ }^{92}$ The continuity obligation is enforceable as if it were the subject of a contractual agreement between the transferee and the residual bank or group company. The extent and duration of the continuity obligation are set out in the BoE's notice and the obligation is not restricted to direct provision of services and facilities to the transferee but it may be wider. ${ }^{93}$

\section{c. Bridge bank}

Through this option all or part of the business of a failing bank is transferred to a company which is wholly owned by the Bank of England (a bridge bank). ${ }^{94}$ For that purpose the Bank of England may issue one or more property transfer instruments. Through a property transfer instrument the BoE may transfer: (a) property, rights and 
liabilities acquired or arising between the making of the instrument and the transfer date, (b) rights and liabilities arising on or after the transfer date in respect of matters occurring before that date, (c) property outside the United Kingdom, (d) rights and liabilities under the law of a country or territory outside the United Kingdom and (e) rights and liabilities covered by legislation (including legislation of the European Union).

The bridge bank option is a major innovation, as failing banks so far have been dealt with either by means of private sector transfer or transfer to public ownership. However, it has been criticized as lacking the clarity of the private sector transfer and public ownership options and presenting difficult challenges for the BoE with respect to competition and management. First, a bridge bank should be managed in a way that maintains the value of its franchise and improves its worth to a private sector purchaser. Second, its form of ownership should not grant it a competitive advantage against other banks. While a bridge bank will be able to take on new business, it should not at the same time compete 'aggressively'. 95 Arguably, the management of the bridge bank will have serious difficulty to distinguish between being competitive, in order to preserve the value of the franchise, and 'aggressively' competitive.

The already discussed Code of Practice will provide with respect to the management and control of bridge banks: (a) the set of objectives of the bridge banks, (b) the content of the articles of association, (c) the content of reports under Section 80(1), (d) arrangements for management and control at different stages and (e) eventual disposal. Thus, the Treasury's draft Code provides a set of bridge bank objectives. ${ }^{96}$ These are subordinate to the SRR objectives, with the latter given precedence even in the event of conflict between the two sets of objectives. ${ }^{97}$

According to the bridge bank objectives, a bridge bank should be a short-term operation, only existing until an appropriate private sector solution can be arranged and implemented. Therefore, the primary bridge bank objective shall be to facilitate the sale of a bridge bank - in whole or in part-to one or more private sector purchasers. In this context, and provided that the private sale objective is not compromised, the BoE should manage its relationship with the bridge bank at arm's length, unless, an arm's length arrangement is not appropriate, due to the short life of the bridge bank. ${ }^{98}$ Where it is not feasible for some or all of a bridge bank's business to be transferred to a private sector purchaser, 'the bridge bank will either be wound up in a manner that meets the special resolution objectives and is in the interests of the remaining creditors of the bridge bank or taken into temporary public ownership.' 99

Where the BoE has made a property transfer instrument in respect of a bridge bank in accordance with Section 12(2), it may also make one or more bridge bank share

95 Mark Hoban, MP (Shadow Minister, Treasury), Hansard HC Vol 483 cols 813-814 (26 November 2008).

$96 \mathrm{Cl} 49-50$ of the draft Code.

97 Ibid cl 53.

98 Ibid cl 51.

99 Ibid cl 52. 
transfer instruments. ${ }^{100}$ Before making a bridge bank share transfer instrument the Bank of England must consult the FSA, and the Treasury. Following the issue of a bridge bank share transfer instrument, under Section 30(2), which provides for the transfer of securities to: (a) a company wholly owned by the BoE (a BoE newco), (b) a company wholly owned by the Treasury (a Treasury newco), or (c) a nominee of the Treasury, ${ }^{101}$ the BoE may reverse the transfer. This is done by means of one or more bridge bank reverse share transfer instruments ${ }^{102}$ in respect of securities issued by the bridge bank and held by a BoE or Treasury newco or a Treasury nominee. Again, before making a bridge bank reverse share transfer instrument the BoE must consult the FSA and the Treasury. ${ }^{103}$ Furthermore, where property, rights, or liabilities are first transferred by property transfer instrument to a bridge bank and later transferred (whether or not by the exercise of a power under this Part of the Act) to another company which is wholly owned by the Bank of England, that other company is an onward bridge bank.

For property transfers under the bridge bank scheme, the Treasury shall make a resolution fund order, ${ }^{104}$ which may include: ${ }^{105}$ (a) a compensation scheme order and (b) a third party compensation order. In the case of a partial property transfers, the resolution fund order must include a provision for third party compensation. ${ }^{106}$ Furthermore, a resolution fund order must prescribe the persons, who will be entitled to a share of the proceeds on disposal of things transferred, the way in which the proceeds will be calculated, and the way in which shares will be calculated. The sums to be paid may be determined by an independent valuer, in which case the order must provide the valuation principles to be applied in making a determination. ${ }^{107}$

\section{d. Temporary public ownership}

Under Sections 13 and 82 of the Act, the third stabilization option is to take the bank concerned or a 'holding company' into temporary public ownership. For that purpose the Treasury may make one or more share transfer orders in which the transferee is: (a) a nominee of the Treasury, or (b) a company wholly owned by the Treasury.

100 Banking Act 2009, SS 30 (1), (2), (5). A bridge bank share transfer instrument is a share transfer instrument which: '(a) provides for securities issued by the bridge bank to be transferred; (b) makes other provision for the purposes of, or in connection with, the transfer of securities issued by the bridge bank'. S 30(3).

101 S 31(1).

102 A bridge bank reverse share transfer instrument is a share transfer instrument which: '(a) provides for transfer to the transferor under the original instrument; (b) makes other provision for the purposes of, or in connection with, the transfer of securities which are, could be or could have been transferred under paragraph (a)'. S 31(3).

103 S 31(5).

104 'A "resolution fund order" is an order establishing a scheme under which transferors become entitled to the proceeds of the disposal of things transferred-(a) in specified circumstances, and (b) to a specified extent.' S 49(3).

105 Ss $52(1)-(3)$.

106 S 52(4).

107 S 58(1)-(3). 
Before bringing into public ownership the Treasury must be satisfied, following consultation with the FSA and the BoE, that two specific conditions are met: ${ }^{108}$

Condition $A$ is that the exercise of the power is necessary to resolve or reduce a serious threat to the stability of the UK financial system,

Condition $B$ is that exercise of the power is necessary to protect the public interest, where the Treasury have provided financial assistance in respect of the bank for the purpose of resolving or reducing a serious threat to the stability of the UK financial system.

The aforementioned Code of practice under Section 5 of the Act will provide the general guidelines about the management of banks taken into temporary public ownership under SRR. Furthermore, where the Treasury has issued a share transfer order for TPO purposes shall provide compensation to the existing shareholders under either: ${ }^{109}$ (a) a compensation scheme order, or (b) a resolution fund order, which may also provide for compensation to third parties. ${ }^{110}$ A resolution fund order made in the context of TPO may require the Treasury to ensure that a bank in temporary public ownership is managed with the aim of maximizing the proceeds available for distribution in accordance with the order, although such objective must remain subordinate to the general SRR objectives. ${ }^{111}$

\subsection{Special insolvency procedure}

\subsubsection{Conditions for granting an insolvency order}

The need for effective bank insolvency laws has been stressed by many commentators. ${ }^{112}$ Thus, the fact that the UK did not have a special bank insolvency regime of a permanent nature and regulators had to rely on general insolvency laws, ${ }^{113}$ remains surprising. Under Part 2 of the Act, the BoE, the FSA, or the Secretary of State, can make an application to the court for a bank ${ }^{114}$ insolvency order, namely, an order to appoint a person to act as bank liquidator under Section 94. The application must nominate a person, who is qualified as an insolvency practitioner, to be appointed as the bank liquidator and the bank must be given notice of an application, in accordance with rules under Section 411 of the Insolvency Act 1986.

The first action that the bank liquidator takes is to arrange for the bank's eligible depositors (ie depositors who are eligible for compensation under the FSCS) to have their accounts transferred or to receive their compensation from the FSCS. Subsequent to this

108 S 9.

109 S 51(2).

$110 \mathrm{~S} 51(3)$.

111 S 58(7).

112 See Eva Hupkes, 'Insolvency: Why A Special Regime for Banks?', in IMF Institute, Current Developments in Monetary and Financial Law (Washington, DC 2005) 471-515; Andrew Campbell, 'Bank Insolvency and the Problem of Nonperforming Loans' (2007) 9 Journal of Banking Regulation 25.

113 For an overview of previous arrangements see Andrew Campbell and Peter Cartwright, Banks in Crisis, The Legal Response (Ashgate Dartmouth, London 2002).

114 Section 91 defines a 'bank' as a UK incorporated/formed deposit taking institution operating under Part 4 of FSMA 2000. The Treasury may, by order, extend the application of Part 2 of the Act to building societies and credit unions (ss 130-131). 
action, the bank liquidator winds up the bank. In order to carry out those actions the bank liquidator has the powers and duties granted under Part 2.

The grounds for applying for an insolvency order are (Section 96(1)):

(a) Ground A: a bank is unable, or likely to become unable, to pay its debts,

(b) Ground B: the winding up of a bank would be in the public interest, and

(c) Ground C: the winding up of a bank would be fair.

Each of the relevant authorities may use different grounds (Section 96(2)-(3)). The BoE a may apply for a bank insolvency order only if: (a) the FSA has informed the Bank of England that the FSA is satisfied that the bank's compliance with the threshold conditions is very problematic, in accord with the General Conditions for the exercise of stabilization powers under Section 7, and (b) the BoE itself is satisfied that: (i) the bank has eligible depositors, and (ii) Ground A or Ground C applies.

The FSA may apply for a bank insolvency order only if: (a) the BoE consents and (b) the FSA is satisfied that: (i) the bank's compliance with the Threshold Conditions is very problematic, in accord with the General Conditions for the exercise of stabilization powers under Section 7, (ii) the bank has eligible depositors, and (iii) Ground A or Ground $C$ applies.

The Treasury may apply for a bank insolvency order only if satisfied (a) that the bank has eligible depositors, and (b) that Ground B applies. The court will make an insolvency order under Section 97, only where the respective conditions as set out above are met.

\subsubsection{Bank liquidation}

A bank liquidator must pursue two objectives. ${ }^{115}$ First, she has to work with the FSCS so as to ensure that as soon as is reasonably practicable each eligible depositor (Objective 1): (a) has the relevant account transferred to another institution, or (b) receives payment from (or on behalf of) the FSCS. Second, she has to wind up the affairs of the bank in a manner that ensures the best result possible for the entire body of bank creditors (Objective 2). While Objective 1 takes precedence over Objective 2, the bank liquidator, who in terms of status is regarded as an officer of the court, ${ }^{116}$ has a duty to work towards both objectives immediately upon appointment.

Evidently, the Treasury's paramount concern in the course of bank liquidation is to ensure a fast payout for depositors or a fast transfer of their accounts without prejudicing the interests of other bank creditors. For this reason, in order to facilitate the achievement of Objective 1 and ensure a fast payout to depositors the FSCS: (a) may make or arrange for payments to or in respect of eligible depositors of the bank, and (b) may make money available to facilitate the transfer of accounts of eligible depositors of the bank. ${ }^{117}$ Furthermore, the Act provides that any transfer by the bank liquidator of eligible 
depositors' accounts from the failing bank to another institution, pursuant to Objective 1, has immediate effect and is valid despite of any consent, legal capacity requirements or other transfer restrictions arising by virtue of contract or legislation or in any other way. ${ }^{118}$ In making the transfer arrangements, the bank liquidator must ensure that 'eligible depositors will be able to remove money from transferred accounts as soon as is reasonably practicable after transfer. ${ }^{119}$ In this context and in order to facilitate the pursuit of Objective 1, a bank liquidator may enter into an agreement under Section 221A of FSMA 2000 (Compensation Scheme: delegation of functions) for the bank liquidator to exercise functions of the FSCS manager. ${ }^{120}$

Section 103 of the Act provides the general powers and duties of bank liquidators and describes the general process and effects of bank insolvency. In a number of areas the powers granted under this provision are in addition to the powers granted by the Insolvency Act 1986 (as applied under the modifications provided in the Banking Act) and the Companies Acts.

The work of the bank liquidator is overseen by a liquidation committee, ${ }^{121}$ which is established once a bank insolvency order is issued. The liquidation committee shall consist initially of three individuals, one nominated by each of the BoE, the FSA and the FSCS. Its duty is to ensure that the bank liquidator properly exercises the functions granted under Part 2 of the Act. As soon as is reasonably practicable, a liquidation committee must recommend $^{122}$ the bank liquidator to pursue one of the actions described in Objective 1, or have the relevant accounts for one class of eligible depositors transferred and pursue a payoff for another. In making a recommendation the liquidation committee must consider whether it is desirable to achieve Objective 1 as quickly as possible, and the means required to achieve Objective 2. Where the liquidation committee has not made a recommendation, the bank liquidator may apply to the court and the court may, in particular, make a direction in lieu of a recommendation if the liquidation committee fails to make one within a period set by the court. ${ }^{123}$

The bank liquidator shall keep the liquidation committee informed of progress towards the achievement of Objective 1 of Section 99 with respect to account transfers or depositor payouts and when in her opinion Objective 1 has been achieved entirely or so far as is reasonably practicable. Subsequently, the liquidation committee must decide whether Objective 1 has been achieved entirely or so far as is reasonably practicable (a full payment resolution), or (b) apply to the court under Section 168(5) of the Insolvency Act 1986.

Where the liquidation committee passes a full payment resolution, the bank liquidator must summon a meeting of creditors, which may elect two or four individuals as new members of the liquidation committee, replacing the members nominated by the BoE and

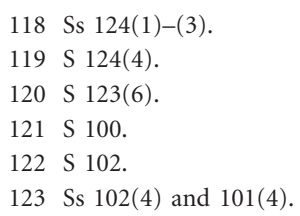


the FSA. Also, the FSCS representative may resign from the liquidation committee increasing the number of replacement members that have to be elected. ${ }^{124}$ Under Section 101(3), a person who has a complaint against any action of the liquidation committee before it has passed a full payment resolution may apply to the court, which may make any order (including an order for the repayment of money). The court under such application or an application of a bank liquidator or of any other interested party may make an order that the liquidation committee is to be treated as having passed a full payment resolution.

If the liquidation committee thinks that the bank liquidator is failing to comply with their recommendation, they must apply to the court for directions under Section 168(5) of the Insolvency Act 1986 (as applied by Section 103 of the Banking Act), and the 'court may confirm, reverse or modify the act or decision complained of, and make such order in the case as it thinks just.'

\subsection{Special administration procedure (bank administration)}

Part 3 of the Act sets out the main features and requirements of the Bank Administration process. The main features of bank administration are that: ${ }^{125}$ (a) it is used where part of the business of a bank is sold to a commercial purchaser in accordance with Section 11 or transferred to a bridge bank in accordance with Section 12. It can also be used in certain cases of multiple transfers under Part 1.

The Bank Administration process starts when the court issues, on the application of the BoE, an administration order appointing a qualified insolvency practitioner as the bank administrator. ${ }^{126}$ The BoE may apply for a bank administration order in respect of a bank if the following conditions are met: (a) Condition 1 is that the BoE has made or intends to make a property transfer instrument in respect of the bank in accordance with Section 11(2) or Section 12(2), (b) Condition 2 is that the BoE is satisfied that the residual bank is unable to pay its debts, or is likely to become unable to pay its debts as a result of the property transfer instrument which the Bank intends to make. ${ }^{127}$

Under the Act, the Bank administrator has two tasks: ${ }^{128}$ (a) to provide support for the commercial purchaser or the bridge bank (Objective 1) and (b) to provide 'normal' administration (Objective 2), as described under Section 140. The pursuit of objective 1 takes priority over objective 2 but a bank administrator is obliged to begin working towards both objectives immediately upon appointment.

Accordingly, the bank administrator is required to ensure that the non-sold or nontransferred part of the residual bank provides services or facilities required to enable,

124 Under S 101(7), even after the removal of their nominated members, the FSA and the Bank of England retain the right to attend the meetings of the liquidation committee, to obtain copies of documents relating to the liquidation committee's business, to make representations to the liquidation committee, and to participate in legal proceedings relating to the bank insolvency.

125 S 136.

126 Ss $141-142$.

127 S 142.

128 S 137. 
in the opinion of the BoE, the private sector purchaser or the bridge bank to operate effectively. ${ }^{129}$ In other respects the process is the same as for normal administration under the Insolvency Act 1986. ${ }^{130}$

In discharging her duties in the pursuit of objective 1 in the context of the bridge bank option, the bank administrator should avoid any action that is likely to prejudice performance by the residual bank of its obligations. So far as is reasonably practicable an agreement entered into includes provision for consideration at market rate. However, the bank administrator enjoys freedom to enter into an agreement on any terms that the bank administrator thinks necessary in pursuit of Objective $1 .^{131}$

The pursuit of Objective 1 ceases if the BoE notifies the bank administrator that the residual bank is no longer required in connection with the private sector purchaser or bridge bank (Objective 1 Achievement Notice). Also a bank administrator who thinks that Objective 1 is no longer required may apply to the court for directions under paragraph 63 of Schedule B1 to the Insolvency Act 1986 and the court may direct the Bank of England to consider whether it should issue an Objective 1 Achievement Notice. ${ }^{132}$

\section{Other important banking act reforms}

\subsection{The new funding arrangements and the enhanced role of the FSCS}

Another important reform introduced by the Banking Act is the revamping of the powers of the FSCS and its transformation into a pre-funded scheme (in due course), in order to discharge properly its new compensation obligations and administrative duties under the SRR, discussed extensively in section 3 of this article. Thus, Part 4 of the Banking Act amends Part 15 of FSMA 2000 as regards funding support for the FSCS. Section 170 of the Act inserts to FSMA a new Section 214A conferring the Treasury the power to make (in due course) regulations to enable levies to be imposed by the FSCS manager for the purpose of maintaining contingency funds (Contingency fund regulations). In addition, Contingency fund regulations may make provision about the establishment and management of contingency funds; in particular, making provision about: (a) the number and size of funds, (b) the circumstances and timing of their establishment, (c) the classes of person from whom contributions to the funds may be levied, (d) the amount and timing of payments into and out of funds (which may include provision for different levies for different classes of person), (e) refunds, (f) the ways in which funds' contents may be invested, (h) procedures to be followed in connection with funds, including the keeping of records and the provision of information.

Section 171 of the Act inserts to FSMA 2000 a new Section 214B, which provides that in the event that one of the SRR stabilization powers has been exercised and the Treasury think that the bank, building society, or credit union was, or but for the exercise of the

129 S $138(1)$.

$130 \mathrm{~S} 145$ of the Act provides a table with the applicable provisions of the Insolvency Act.

131 S 138(4).

132 S 139. 
stabilization power would have become, unable to satisfy claims against it, the Treasury may require the scheme manager to contribute towards expenses connected with the exercise of the stabilization power. The Treasury shall make regulations specifying: (a) what expenses the scheme manager may be required to contribute towards, (b) providing for independent verification of the nature and amount of expenses incurred, and (c) providing for the method by which amounts to be contributed are to be determined. The regulations must ensure that contributions required do not exceed the amount of compensation that would have been payable under the scheme if the stabilization power had not been exercised and the bank had been unable to satisfy claims against it.

Sums levied for the purpose of maintaining a contingency fund may be paid to the Treasury and will be treated as National Loans (under Section 12 of the National Loans Fund) invested as part of the National Loans Fund, with all accrued interest credited to the contingency fund. The Treasury is obliged to comply with any request of the scheme manager to arrange for the return of sums for the purpose of making payments out of a contingency fund. ${ }^{133}$ The scheme manager may also borrow money from the National Loans Fund for the purpose of funding expenses incurred or expected to be incurred under the scheme. ${ }^{134}$ This ensures that the FSCS has access to immediate liquidity through borrowing from the public sector.

Indicative of the enhanced standing of the FSCS, beyond its role in making compensation under various compensation orders, is the power given to it under Section 123 (4) of the Act in the context of the Special Insolvency Procedure. Thus, the FSCS is entitled to participate in proceedings for or in respect of a bank insolvency order, under Section 94. Also, a bank liquidator must (a) comply with a request of the FSCS for the provision of information, and (b) provide the FSCS with any other information which the bank liquidator thinks might be useful for the purpose of co-operating in the pursuit of Objective 1 of Section 99 (bank liquidation). ${ }^{135}$

Although FSCS pre-funding is not to be introduced immediately, but in due course, when the financial state of the British banks improves, it has raised much controversy. Strong opposition to FSCS pre-funding has been expressed by the British Banks Association, ${ }^{136}$ given the costs it entails for British banks, and the Conservative opposition. The first objection revolves around the issue of fairness. Namely, all participating institutions will contribute relatively equally, notwithstanding their different risk profiles. The second argument is that FSCS pre-funding is capital intensive, while investing big sums in highly liquid instruments is not the best use of funds. The third argument is that, as regards depositor protection, the issue is not whether the FSCS has adequate funds to pay out deposits, but whether it has access to adequate lines of liquidity, which is

133 S 172 of the Banking Act 2009 inserting a new Section 223A (Investing in National Loans Fund) to FSMA 2000.

134 S 173 inserting a new Section 223B (Borrowing from National Loans Fund) to FSMA 2000.

135 Ss 123(5).

136 See Angela Knight, 'Financial Stability and Depositor Protection: Strengthening the Framework, BBA Response to the Tripartite Consultation Document', 8 April 2008, 2. 
ensured by having recourse to public funds. Finally, it is suggested that depositors are not concerned with fast payouts in case of bank failures but continuity of service. ${ }^{137}$

Pre-funding is essentially based on the so-called 'polluter pays' principle. Accordingly, the main weakness of the above arguments is that they try to shift the cost of the externalities created by the reckless running of a bank and excessive risk taking from those who are naturally responsible to bear it, the bank shareholders, to the taxpayer. Essentially, pre-funding forces banks to internalize the costs of their operation and injects a certain degree of market discipline. Also, as discussed in section 2 of this article, the Northern Rock crisis proved beyond any doubt the central role that adequate deposit insurance and swift depositor payouts play in averting the most debilitating of bank risks: a depositors' run. Finally, pre-funding allows for spreading the costs of bank failure over a longer period of time, which reduces the extent to which firms (or the taxpayer) have to contribute after such failure, when financial stress may be greater. As a result, it is easier to find a private sector buyer for the failing bank. ${ }^{138}$

\subsection{Financial stability committee}

Section 238 of the Banking Act inserts a new Section 2A to the Bank of England Act 1998 which adds a financial stability objective to the Bank's remit. The BoE's actual duty in this respect 'shall be to contribute to protecting and enhancing the stability of the financial systems of the United Kingdom'. The ambit of the BoE's objective in relation to the Financial Stability is determined by the BoE's court of directors. To this effect Section 238 also inserts a new Section 2B to the Bank of England Act 1998 which mandates the establishment of a sub-committee of the court of directors of the BoE called the "Financial Stability Committee". The Committee's membership shall consist of: (a) the Governor of the Bank, who shall chair the Committee (when present), (b) the Deputy Governors of the Bank, (c) 4 directors of the Bank, appointed by the chair of the court of directors, (d) a Treasury representative as a non-voting member, and (e) other non-voting members that the Committee may co-opt. Section 239(2) of the Act describes the functions/responsibilities of the Committee, which are:

(a) to make recommendations to the court of directors... about the nature and implementation of the Bank's strategy in relation to the Financial Stability Objective,

(b) to give advice about whether and how the Bank should act in respect of an institution, where the issue appears to the Committee to be relevant to the Financial Stability Objective,

(c) in particular, to give advice about whether and how the Bank should use stabilization powers under Part 1 of the Banking Act 2008 in particular cases,

(d) to monitor the Bank's use of the stabilization powers,

137 Mark Hoban, MP, Hansard HC Vol 483 cols 802-803 (26 November 2008).

138 This is also the essence of the arguments put in favour of pre-funding by Treasury. See Ian Pearson (Economic Secretary to the Treasury) Hansard HC Vol 483 cols 806-807 (26 November 2008). 
(e) to monitor the Bank's exercise of its functions under Part 5 of the Banking Act 2009 (inter-bank payment systems), and

(f) any other functions delegated to the Committee by the court of directors for the purpose of pursuing the Financial Stability Objective.

\section{SRR effectiveness and the UK system of banking supervision}

\subsection{Issues of governance arising from the application of the SRR}

The powers of the BoE and the Treasury under the SRR are sweeping and possibly unprecedented. For example, concerns have been raised by many commentators, and the House of Lords, about the use of Section 75 of the Act that grants the Treasury unrestrained power to change the law, ${ }^{139}$ for the purpose of enabling the SRR powers to be used effectively. This can include changing any legislation or any provision or common law and, at least in relation to a particular exercise of power under the Banking Act. Although this power is subject to Parliamentary scrutiny, anything done under an order, before Parliament approves it, will stand. ${ }^{140}$ The Treasury's justification for this provision is that 'in the absence of such a power ... there is a real and significant risk that the Authorities may not be able to effect fully a transfer' which 'could lead to serious adverse implications for the public interest through risks to financial stability, protection of depositors or the public funds'. ${ }^{141}$

Another illustration of the sweeping powers that the relevant authorities have acquired under the Banking Act is the discussed above property or share transfers, where they are entitled to even interfere with contracts and legal and commercial relationships between the residual bank or group company and the commercial purchaser or the bridge bank, or between the transferred bank and a former group company. ${ }^{142}$ Obviously, if this power is exercised against a UK subsidiary of a foreign bank, it could create undesirable consequences to UK relations with the home country of the foreign subsidiary. Finally, concerns have been raised with respect to BoE accountability in making transfer orders in the context of the bridge bank option, which, although in its essence is a form of temporary public ownership, are not subjected to Parliamentary scrutiny. ${ }^{143}$

However, the most difficult and challenging aspect of the SRR will be to ensure that the relevant authorities have the appropriate standing in public and industry consciousness as to enjoy necessary confidence as impartial arbiters of private interests in

139 Select Committee on Delegated Powers and Regulatory Reform, 'First Report, Banking (No.2) Bill [HL]', 18 December 2008. 140 S 75(8). It should be noted here that use by the Treasury of a wide power in a manner that was not intended when legislation was passed is far from unprecedented. The most recent example is the use of anti-terrorism legislation to achieve the freezing of the assets of the UK branch of the failed Landsbanki bank of Iceland. See Landsbanki Freezing Order 2008, SI 2668/2008, which was issued by Treasury in exercise of the powers conferred by Sections 4 and 14 of and Schedule 3 to the Anti-terrorism, Crime and Security Act 2001 (2001, c. 24).

141 See $\mathrm{n} 138$.

142 Banking Act, ss 66 \& 68 .

143 See n 137. 
exercising the SRR stabilization options, which have very strong distributive aspects. The difficulties that may arise in this context are discussed in the next paragraph.

\subsection{SRR and banking supervision}

As the Economist observes: 'bank bail-outs always involve an agonizing balancing act: systemic stability versus moral hazard; fighting recession by lending to small businesses versus safeguarding the taxpayer's investment'. ${ }^{144}$ Also the exercise of the SRR stabilization options will affect the state of competition in the banking industry, the value of financial assets comparable to those of the failing bank, employment relations and local financial interests. Characteristic examples of the governance issues involved and the massive public discussion and reactions that the exercise of the SRR stabilization powers may create constitute the political parties' and press' criticism of the Northern Rock nationalization. An even bigger, though indirectly relevant, example constitutes the massive public controversy raised by the government induced HBOS merger with Lloyds bank, and especially the opposition to it by Scottish economic circles, which regarded it as detrimental to Scottish interests. ${ }^{145}$

The UK authorities will never be able to totally avoid the controversy caused by the exercise of, inevitably, arbitrary public powers with respect to failing bank assets affecting the interests of existing shareholders and creditors in the context of the SRR. To minimize, however, controversy and the ensuing public upheaval they could have done two things: (a) create a sound legal framework that provides robust safeguards of the economic interests and legal rights of all constituencies concerned (depositors, other bank creditors, the Treasury, bank shareholders), and (b) furnish it with a functional institutional structure that minimizes controversy. The UK authorities have achieved only the first objective. The second objective could have been achieved either though a wholesale import of the US system or the reform of the Tripartite system in order to enhance the standing of UK bank regulators and their credibility. The latter would mean that the structural problems of the Tripartite arrangement, as exposed by the Northern Rock crisis, were properly addressed.

The wholesale import of the US model, instead of the complex SRR mechanisms, created by the Act, would have only required the serious revamping of the powers of the FSCS, without significantly eroding the existing regulatory powers of the BoE or of the FSA. The FDIC has the ability to take a bank into federal administration if the bank violates minimum capital requirements or other prudential obligations, or is not able to

144 Leader, 'Call it Off, Letting Lloyds TSB Proceed with its Takeover of HBOS is a Mistake', The Economist (6 November 2008) $<$ http://www.economist.com/opinion/displaystory.cfmstory_id=12562335\&fsrc=rss > accessed 23 December 2008.

145 'Opposition to the proposed terms of the merger between HBOS and Lloyds TSB reached fever pitch this week following the campaign by two of Scotland's most senior bankers to keep HBOS as a standalone institution. The "Independent HBOS" campaign aims to encourage smaller investors, who own about $20 \%$ of the bank's shares, to vote against Lloyds TSB taking over the reins of struggling HBOS on 10 December. Sir George Mathewson, a former chief executive at Royal Bank of Scotland, says that the Lloyds TSB deal gives HBOS' two million smaller shareholders only half of the true value of their investment.' Rhian Nicholson, 'Opposition grows over HBOS-Lloyds deal', Interactive Investor (10 November 2008) <http://www.iii.co.uk/articles/ articledisplay.jsp?section=Banking\&article_id=9964089> accessed 10 December 2008. For the competition concerns that mitigate against the merger see Leader, The Economist, n 144. 
meet its creditor claims. The FDIC acquires a controlling interest and other shares in the company are frozen. A new team assumes the management of the bank and is assigned the task of rescuing it and if possible return it to profitability. If this goal is achieved, then the bank is returned to the private sector with any profits made in the interim shared between the FDIC and the shareholders. In the meanwhile, the failing bank's shares are taken off the market, eliminating the incomprehensible situation where a rescued bank remains listed with the market effectively trading the government's guarantees, ${ }^{146}$ as is currently the case with a very large UK based bank.

However, given the Treasury's choice for a pluralistic structure in terms of SRR administration and the granting of the biggest responsibility for its running to the BoE, the Treasury should have also ensured that it had taken the necessary steps to raise public confidence in UK regulators by enabling them to discharge more effectively their supervisory duties. The fact that the Act is not addressing the essence of the Tripartite arrangement might lead to truly undesirable consequences.

First, and despite the establishment of a financial stability committee in the BoE (under Section 238), the separation between the authority that discharges the duty of supervision of liquidity (the FSA) and has the information about the financial state of a banking institution and the institution that provides the liquidity (the BoE) remains. ${ }^{147}$ Secondly, the Tripartite arrangements have been heavily criticized both with respect to lack of clear leadership structure with respect to specific areas and with respect to flows of information between the authorities. ${ }^{148}$

The above dysfunctions, which remain largely un-addressed, despite the significant improvements made by recent legislation, and the fact that all parties decline to reconsider risk-based regulation may have far reaching consequences, even for the effective operation of the SRR. A discredited regulator that has evidently failed in its job, in the course of a future crisis, will probably hesitate to trigger the SRR and will do so only at the very last moment, when it is possibly too late and a depositors' run or a market price collapse, due to lack of confidence in the failing bank, has already materialized. This will diminish the public standing of the UK authorities at the very moment that they will have to discharge their powers under the SRR and make decisions with far reaching economic consequences. Although the UK is a country whose public authorities have traditionally been beyond the suspicion of corruption, regulatory failure is bound to undermine the standing of the SRR authorities. Compulsory asset and share transfers under the SRR, especially in the context of the discussed above partial transfers, which inevitably involve cherry picking, are bound to have far reaching economic

146 Kern Alexander, John Eatwell, Avinash Persaud and Robert Reoch, 'Financial Supervision And Crisis Management in the EU', Study prepared for the European Parliament's Committee on Economic and Monetary Affairs, IP/A/ECON/IC/2007-069, December 2007.

147 It has been strongly argued that this distinction is one of the fundamental flaws of the Tripartite arrangements. See statement of Professor Buiter before the Parliamentary Committee. The Run on the Rock, 105.

148 Ibid 107-110. 
consequences for some of the failing bank constituencies. ${ }^{149}$ A regulator with diminished standing, as a failed regulator normally is, will find it very hard to withstand the ensuing criticism, unlike a regulator that enjoys public confidence, because of its supervisory record. A good example of the difference in the handling of a crisis by a public authority, depending on its standing and the public confidence it enjoys, is the different reception and effectiveness of the Bush administration treatment of the 9/11 attacks and of the global financial crisis. In the latter case, the administration's diminished authority, because of lack of public confidence in its actions, greatly undermined the effectiveness of those actions. ${ }^{150}$

Although the Parliamentary Report has stopped short from requesting the reform of the Tripartite structure with a single financial services regulator, it was clear from it that its members thought of the current system as containing several dysfunctional aspects. The Northern Rock crisis has done nothing to reaffirm the argument in favour of a single regulator: better supervision because of specialization and economies of scale, especially as regards flows of information. ${ }^{151}$ If nothing else the Northern Rock debacle has proved that flows of information between different teams in a large bureaucratic regulatory organization are as problematic as inter-organizational flows.

The best alternative to the current Tripartite arrangement is arguably not a return of banking supervision to the BoE. For many reasons, including clear division of regulatory responsibility the Twin Peaks approach to financial supervision seems far superior. ${ }^{152}$ Under a Twin Peaks structure the FSA would remain responsible for supervision of business conduct, of market conduct and market integrity (insider dealing, market manipulation), and consumer protection. The other authority (the BoE or a new authority) would supervise the compliance of banks, securities firms, investment funds, with systemic stability (prudential) regulations, including liquidity and capital adequacy regulations. The fact that preliminary European legislation seeks to impose capital requirements on investment funds, ${ }^{153}$ in order to safeguard systemic stability, further reinforces the view for a specialized prudential regulator for the entire financial services industry.

Arguably, infractions of conduct of business, consumer protection or market integrity regulations very rarely lead to systemic collapse, unless they are of a very grand scale and

149 Eg, massive have been the governance problems raised by the structure and administration of the US' Troubled Asset Relief Programme (TARP), the so-called Paulson package, from which tentative comparisons may also be drawn. Liam Halligan, 'Paulson Torpedoes his own TARP', The Telegraph, (15 November 2008) <http://www.telegraph.co.uk/finance/3465298/Paulson-torpedoeshis-own-TARP.html > accessed 12 December 2008.

150 See E A Posner and A Vermeule, 'Crisis Governance in the Administrative State: 9/11 and the Financial Meltdown of 2008', 13 November 2008, University of Chicago Law \& Economics, Olin Working Paper No. 442.

151 See for an overview of the debate on the merits and de-merits of having a single regulator for the financial services industry Howard Davies and David Green, Global Financial Regulation (Polity, Cambridge 2008) 189-191.

152 M Taylor, "“Twin Peaks": A Regulatory Structure for the New Century', CSFI (Committee for the Study of Financial Innovation), London, 1995 and 'The Institutional Structure of Financial Regulation', in Goodhart et al., n 1, 142-189.

153 On 23 September 2008, the European Parliament (EP) adopted the Rasmussen Report on Hedge funds and Private Equity and called the European Commission to submit to Parliament, "a legislative proposal or proposals on the transparency of hedge funds and private equity". The Rasmussen Report, inter alia, calls for capital requirements to be imposed on hedge funds. See 'Resolution of 23 September 2008 with Recommendations to the Commission on Hedge funds and Private Equity' EP 2007/2238(INI). 
systematic, seriously harming the reputation of the marketplace and massively forcing out investors. Therefore, the fact that the interconnection of the two areas is strong but yet limited would allow the two agencies to operate independently and with minimum overlap of their supervisory remit, within, of course, a tightly structured framework of cooperation.

Appointing the BoE as the financial stability regulator would also mean that its powers under the SRR would be transferred to an independent financial stability committee. Also, the Twin Peaks approach would again raise the question of the role of the Central Bank in drawing monetary policy, given the eventual conflict that could arise by being both a bank regulator and a setter of interest rates. However, in Europe absolute central bank independence in setting monetary policy is very much an innovation of the past decade. It constitutes the result of the establishment by the Chancellor of the Monetary Policy Committee (MPC) in the $\mathrm{BoE}^{154}$ and of the establishment of the European Monetary Union, which gives interest rate setting authority, for the Eurozone member states, to the European System of Central Banks (ESCB). Both the ESCB and the MPC have a mixed record as monetary authorities and were slow to anticipate the marching deflation that hit the UK and Eurozone economies in the middle of 2008. Also, the UK's monetary policy structure is reversible without having to enact a new Treaty. Accordingly, in the event that the BoE were to become the financial stability regulator, inevitably the MPC would have to operate independently of the BoE. As a result, outside members would have to be in the majority, although the MPC would still be chaired by the Governor of the BoE and use the Bank's support infrastructure and data, as well as that of independent sources. ${ }^{155}$

\section{Conclusion}

Notwithstanding reputation consequences and public expenditure, in many ways Northern Rock's failure was 'a blessing in disguise' for the UK banking system. As a result of this crisis the UK had robust liquidity arrangements, when the 'phoney war' ended and global markets were hit by a gigantic wave of panic selling and massive deleveraging. In the intervening year, the failure of a relatively small bank had led to a major shift in attitudes and much higher regulatory and governmental readiness. The orderly handling of the second and most important phase of the global crisis has enhanced the reputation of the UK as a leading global financial centre. Of course, the relevant rescue package came at a great cost to the taxpayer and is not clear yet if it has saved the financial institutions concerned from the consequences of their un-thoughtful actions. In this climate of steady improvement the UK authorities have enacted legislation and adopted new regulations in a number of areas, including liquidity regulation, which will seriously enhance the quality of banking supervision in the UK. The reforms 
introduced by the Banking Act 2009 and especially the establishment of a far reaching SRR for failing banks provide better protection of depositors and furnish the authorities with the appropriate tools to intervene early in the case of a failing bank and prevent systemic instability.

However, the jigsaw of reform is far from complete. The fact that the stabilization options of the SRR require the taking of decisions that will potentially have serious distributive effects means that the standing of the public authorities participating in the decision-making process is of cardinal importance. Naturally, a failed regulator is a regulator of diminished standing and credibility. As a result, the SRR authorities may find themselves in a weakened position when called to make decisions with distributive effects under the stabilization options of the SRR. This argument strengthens further the case for an urgent re-opening of the debate on UK regulatory structures dealing with the supervision of banks, given also the way the Tripartite structure responded to the Northern Rock crisis. In this context, the merits of a Twin Peaks approach, where one regulatory authority, the FSA, is responsible for the supervision of financial firms with respect to market conduct, conduct of business and consumer regulations, and another, the BoE or a new specialized prudential regulator, is responsible for overseeing financial firms' (including investment funds) compliance with financial stability regulations should be re-examined.

The advantage of having a single regulator dealing with both of the main aspects of financial supervision is far from clear. Furthermore, as has been argued in this article, the quality of banking supervision is bound to have a serious impact on the operation of the SRR and may, in the end, seriously undermine its effectiveness. Therefore, any doctrinal adherence to the unproven single regulator hypothesis with respect to the banking industry, which is the most important and globalized sector of economic activity in the country and central to the UK's sustained prosperity, should be seen with serious scepticism. 